\title{
IDENTIFIKASI SITUS KAPAL KARAM BERSEJARAH “KARANG PANJANG” DI PERAIRAN PULAU LAUT NATUNA
}

\section{IDENTIFICATION OF KARANG PANJANG HISTORICAL SHIPWRECK IN PULAU LAUT NATUNA}

\author{
Ira Dillenia dan Rainer Arief Troa \\ Pusat Penelitian dan Pengembangan Sumberdaya Laut dan Pesisir, \\ Badan Penelitian dan Pengembangan Kelautan dan Perikanan, Kementerian Kelautan dan Perikanan RI \\ Kompleks Bina Samudera Gd.II Balitbang KP Lt.4, Jl. Pasir Putih II Ancol Timur, Jakarta 14430 \\ Telp: (021) 64700928, 64700755 Ext : 3118, Faks: (021) 64711654 \\ Email: ira.dillenia01@gmail.com
}

Diterima tanggal: 24 Oktober 2016 diterima setelah perbaikan 25 Januari 2017, disetujui tanggal: 13 Februari 2017

\begin{abstract}
ABSTRAK
Pulau Laut dan kawasan perairan Natuna secara keseluruhan berdasarkan bukti sejarah sejak abad 10 M, telah menjadi jalur lintas laut untuk berbagai kapal dagang asing yang akan masuk ke wilayah Nusantara. Dalam perjalanannya masuk ke Natuna, banyak dari armada kapal tersebut yang karam dan akhirnya tenggelam di kawasan perairan kepulauannya. Artinya, potensi keberadaan situs arkeologi bawah laut di kawasan ini sangat besar yang belum semuanya teridentifikasi. Karena itu, penelitian arkeologi maritim yang mendasari tulisan ini bertujuan mengidentifikasi bentuk dan struktur kapal karam, serta menggali nilai historis didalamnya. Fokus lokasi pada Situs Karang Panjang, Perairan Pulau Laut Natuna. Metode penelitian yang digunakan adalah survei akustik bawah air (side scan sonar), penyelaman, dan wawancara dengan masyarakat setempat. Hasil penelitian menunjukkan bahwa Situs Karang Panjang merupakan situs kapal karam bersejarah berteknologi mesin uap, struktur kapal berbahan campuran besi dan kayu dengan sebagian besar telah ditumbuhi karang sehingga telah menyatu dengan ekosistem bawah lautnya. Hal ini menjadikan Situs Karang Panjang berpotensi menjadi obyek wisata selam kapal karam (wreckdive) sebagai bagian gagasan Marine EcoArchaeological Park di atas.
\end{abstract}

Kata kunci: Pulau Laut Natuna, Situs Karang Panjang, struktur kapal, side scan sonar, selam kapal karam

\section{ABSTRACT}

Based on historical brieft and archaeological resources, the waters of Pulau laut Natuna had been travelled since 10 $C E$ by the foreign merchant ships coming to the Nusantara. Some of them were lost in the waters of Natuna. Those are a very big potency of the maritime archaeological site in Natuna. Hence, the objective of this paper is identification the shape, the structure and the historical value of the shipwreck in Karang Panjang Site, in the water of Pulau Laut Natuna. The method used in this research were underwater acoustic (side scan sonar), diving and interview with the local community of the site.The result showed that the Karang Panjang site was the historical shipwreck with the steamship technology and the ship's structure using compund of wood and metal. The most of the shipwreck hull was covered by the coral reefs. It had fused with the marine ecosystem. This makes the site is potentially be the wreck dive and the marine tourism attraction. It is a strategy part of the Marine Eco-Archaeological Park model.

Keywords : Pulau Laut Natuna, Karang Panjang Site, the shipwrek's structure, side scan sonar, wreck diving

\section{PENDAHULUAN}

Situs arkeologi bawah laut berpotensi untuk menjadi obyek wisata bahari yang dapat berperan menjadi pusat pertumbuhan ekonomi pada kawasan pulau. Situs ini umumnya terdiri atas bangkai kapal karam dan muatan kapalnya yang kandas di dasar perairan yang menyimpan nilai historis tinggi. Rentang waktu ratusan tahun telah menyebabkan struktur kapal didiami beragam jenis ikan dan terumbu karang. Sehingga, situs kapal karam menjadi sebuah ekosistem baru dengan biodiversitas dan keindahan terumbu karang yang menakjubkan (Gambar 1). Kenyataan ini yang mendasari timbulnya gagasan situs arkeologi bawah laut dan ekosistem perairannya

Identifikasi Situs Kapal Karam Bersejarah "Karang Panjang” Di Perairan Pulau Laut Natuna - Ira Dillenia dan Rainer 
dijadikan Taman Eko-Arkeologi Bawah Laut (Marine Eco-Archaeological Park). Di sini, aspek pemanfaatan insitu situs sebagi daya tarik wisata bahari yang memperhatikan kelestarian ekosistem dan nilai historis situs akan menggeliatkan roda ekonomi masyarakat. Pada gilirannya, masyarakat sendiri akan melakukan perlindungan sehingga keberlanjutan dan kelestarian sumber daya dapat terjaga. Gagasan tersebut berbasis pada metode preservasi insitu yang digaungkan secara luas oleh UNESCO untuk mengatasi maraknya perusakan dan pengangkatan ilegal (threats) terhadap situs arkeologi maritim yang merupakan warisan budaya bawah air suatu negara (UNESCO, 2006).

Pulau-pulau kecil terdepan di perairan Natuna merupakan bagian penting dalam kedaulatan wilayah Negara Kesatuan Republik Indonesia (NKRI) karena menjadi titik referensi yang menghubungkan garis pangkal laut kepulauan untuk batas wilayah NKRI pada Kawasan Laut Tiongkok Selatan. Kawasan Natuna secara keseluruhan berdasarkan bukti sejarah sejak abad $10 \mathrm{M}$, telah menjadi jalur lintas laut untuk berbagai kapal dagang asing yang akan masuk ke wilayah Nusantara. Dalam perjalanannya masuk ke Natuna, banyak dari armada kapal tersebut yang karam dan akhirnya tenggelam di kawasan perairan kepulauannya. Menurut laporan hasil riset P3SDLP (Dillenia et al., 2012), di perairan Natuna Besar berhasil diidentifikasi sisa struktur kapal dan fragmen tinggalan keramik disekitarnya. Dari data penelitian Puslit Arkeologi Nasional (Harkantiningsih, 2010), disebutkan bahwa artefak keramik di sepanjang pesisir dan perairan Natuna diklasifikasikan menjadi empat masa dalam Dinasti Cina kuno, antara lain Dinasti Song (960 - 1279), DinastiYuan (1271-1368), Dinasti Ming (1368) dan Dinasti Qing (1644 1912). Bukti-bukti tersebut menegaskan bahwa Perairan Natuna merupakan salah satu perairan Maritim yang menjadi penghubung antara Tiongkok dengan pusat-pusat perekonomian yang tumbuh di wilayah Asia Tenggara (Schottenhammer, 2012). Bahkan, saat itu Pulau Natuna telah menjadi lokasi strategis untuk persinggahan kapal-kapal yang dari dan hendak menuju barat dan timur. Posisi strategis Natuna ini dapat disamakan dengan negara Singapura saat sekarang (Wibisono, 2014). Terkait dengan tinggalan arkeologis struktur kapal karam, dapat menjadi bukti yang memperkuat perkembangan sejarah dan IPTEK kemaritiman bagi kawasan perairan di lingkungan Situs tersebut (Muckleroy, 1998).

Di bagian utara Pulau Natuna Besar, yaitu pada kawasan perairan Pulau Laut berhasil diidentifikasi 4 situs kapal karam bersejarah (Gambar 2). Keempat situs tersebut adalah: (1) Situs Kapal Korea; (2) Situs Kapal Kayu; (3) Situs Karang Kia; (4) Situs Karang Panjang. Survey lapangan untuk identifikasi situs dilakukan pada tahun 2015 dengan menggunakan teknologi akustik bawah air (side scan sonar) yang diverifikasi melalui penyelaman (Troa et al., 2015). Kemudian, pada tahun 2016 ini dilakukan observasi ekosistem bawah laut dan identifikasi struktur kapal dan artefaknya melalui metode penyelaman yang difokuskan pada Situs Karang Panjang. Situs ini memiliki struktur dan kerangka kapal karam yang masih lebih lengkap dibandingkan ketiga situs lainnya itu (Dillenia et al., 2016). Tulisan ini dibuat dengan tujuan untuk mengidentifikasi bentuk dan struktur kapal karam serta mengungkap nilai historis didalamnya. Kondisi ekosistem dan biodiversitas bawah laut juga dibahas dalam keterkaitannya dengan situs. Pembangunan kawasan pulau terdepan, terutama di Natuna sangat gencar dilakukan saat era pemerintahan sekarang. Salah satu bentuk kontribusi hasil riset dalam memacu laju pertumbuhan ekonomi pulau terdepan NKRI adalah melalui gagasan menjadikan pulau terdepan Natuna sebagai Taman Eko-Arkeologi Bawah Laut (Marine Eco-Archaeological Park). Sejalan dengan itu, kegiatan identifikasi situs kapal karam menjadi bagian penting untuk menunjang keberhasilan pencapaian sasaran tersebut di atas.

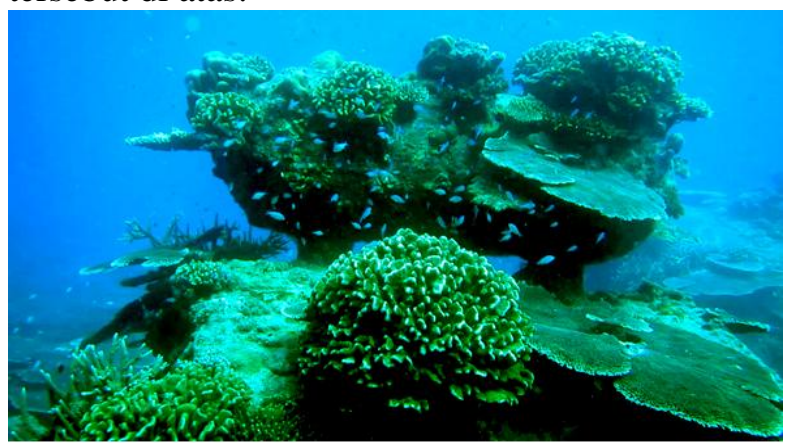

Gambar 1. Situs kapal karam di Perairan Karang Panjang Pulau Laut yang menjadi habitat bagi terumbu karang

Figure 1. Karang Panjang Shipwreck in Pulau Laut which had become habitat for the coral reefs Sumber: Hasil survei dan penyelaman, 2016 


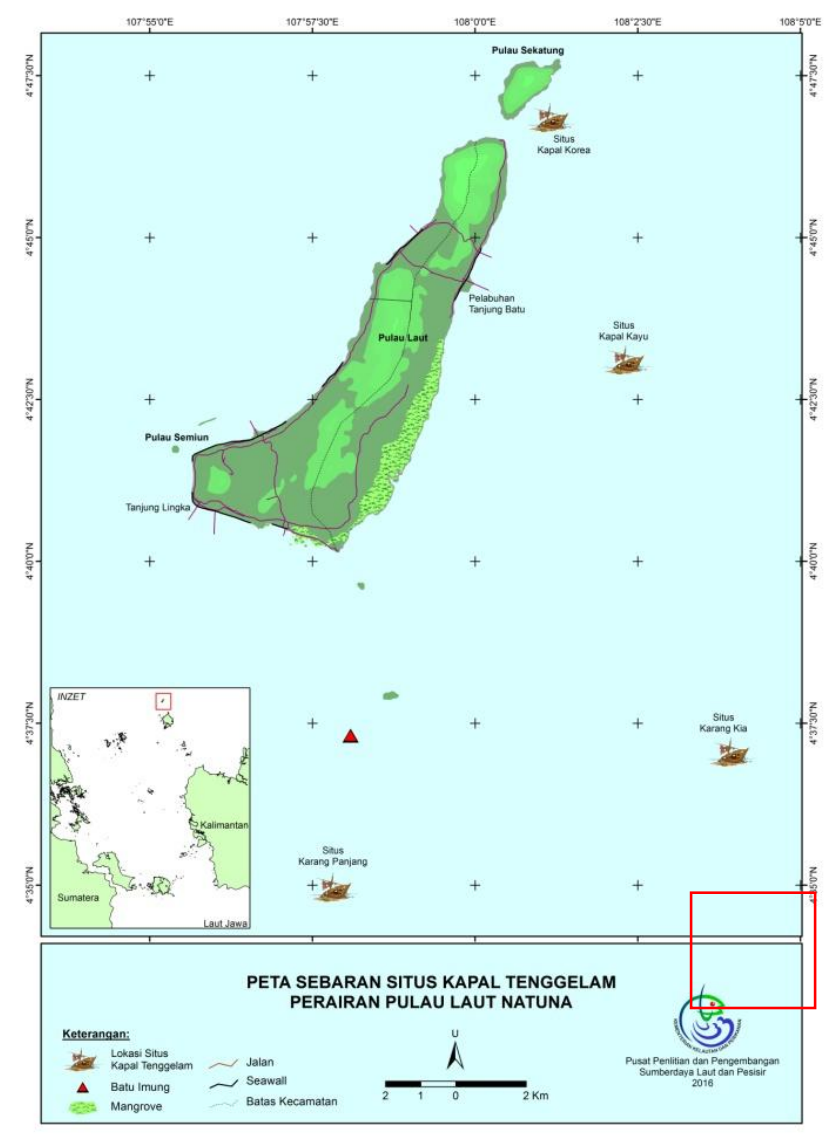

Gambar 2. Sebaran situs kapal karam di Perairan Pulau Laut Natuna

Figure 2. Ancient shipwrecks in Pulau Laut Natuna Sumber: Pengolahan data, 2016

\section{BAHAN DAN METODE}

Dalam penulisan ini, digunakan metodologi deskriptif-analitis menggunakan data hasil survei lapangan dan studi arsip historis. Pengumpulan data lapangan telah dilaksanakan pada bulan Oktober 2015 dan Agustus 2016. Identifikasi terhadap situs kapal digunakan peralatan geofisika akustik bawah air yaitu Starfish 452 F Side Scan Sonar dan echosounder Hi-Sounder HD-380. Side scan sonar digunakan untuk mengetahui gambaran atau citra dasar laut daerah survei. Sistem perekamannya pada dasarnya sama dengan sistem perekaman echosounder dimana tranduser yang berfungsi ganda sebagai source maupun receiver dan dipasang pada kedalaman 1 meter dibawah permukaan air laut atau dapat juga di- towing seperti seismik. Pada kegiatan survey, alat side scan sonar dipasang dengan cara ditempelkan oleh besi disamping kapal survey untuk menghindari tersangkut oleh batuan atau terumbu yang berada di bawah air laut (Gambar 3). Gelombang suara yang digunakan side scan sonar ini mempunyai frekuensi mid-band 450 $\mathrm{kHz}$ CHIRP yang merupakan gabungan antara kemampuan deteksi dan resolusi. Side scan sonar Starfish banyak digunakan untuk penelitian geofisika kelautan karena dapat memetakan dasar laut, medeteksi dan mencari jalur kabel, pipa laut, kapal karam dan obyek-obyek bawah air lainnya. Menurut Gron et al. (2015), metodologi akustik bawah air sangat bagus dalam mencitrakan struktur kapal karam dan memetakan morfologi dasar laut pada lingkungan Situs.

Verifikasi data bawah air dilakukan dengan metode penyelaman (Gambar 4). Observasi dan pengambilan gambar atau foto terhadap bentuk struktur kapal karam dan bagian-bagian kapal, biota dan terumbu karang pada lingkungan Situs dilakukan langsung di bawah air. Hasil rekaman foto dan film ini kemudian diamati kembali untuk dilakukan identifikasi terhadap Situs dan lingkungan perairannya secara deskriptif. Untuk melengkapi data historis, dilakukan metode wawancara dengan narasumber dari tokoh masyarakat yang secara turun-temurun masih menyimpan kisah tentang karamnya kapal tersebut dan kesejarahannya. Berdasarkan hasil analisis dan interpretasi bentuk dan struktur kapal dari citra side scan sonar, kemudian dikompilasi dengan pendekatan nautical archaeology (Green, tahun 2004) untuk interpretasi jenis kapal dan aspek historis didalamnya. 


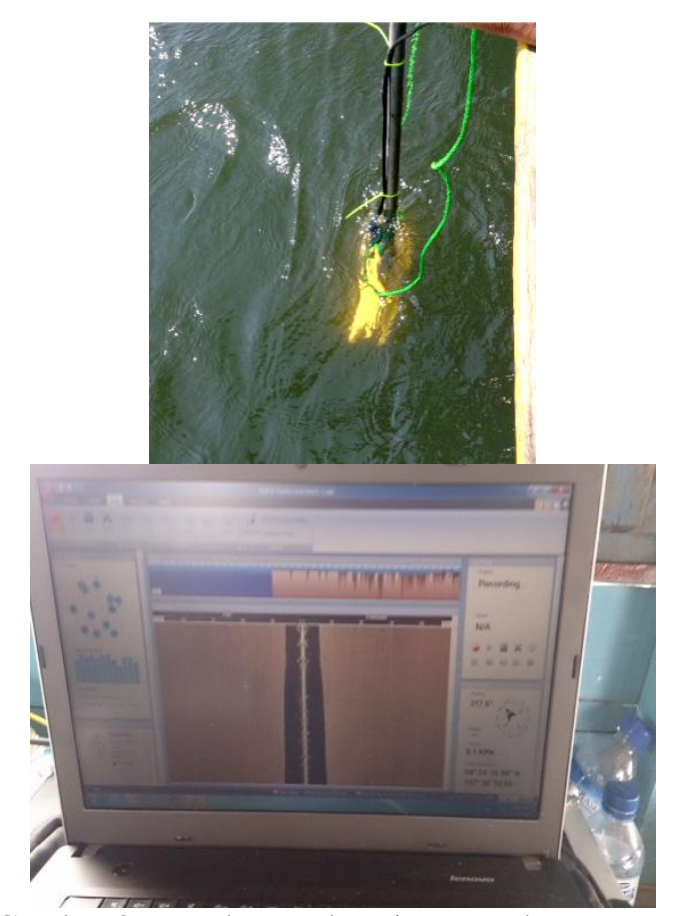

Gambar 3. Tranduser sebagai source dan receiver gelombang akustik (gambar kiri);

Citra dasar laut teramati secara real-time dalam monitor di atas kapal (gambar kanan);

Figure 3. Tranducer as a source and receiver of marine acoustic device (left); seabed anomaly observed by real-time through monitor from the ship (right)

Sumber: Hasil survei, 2015

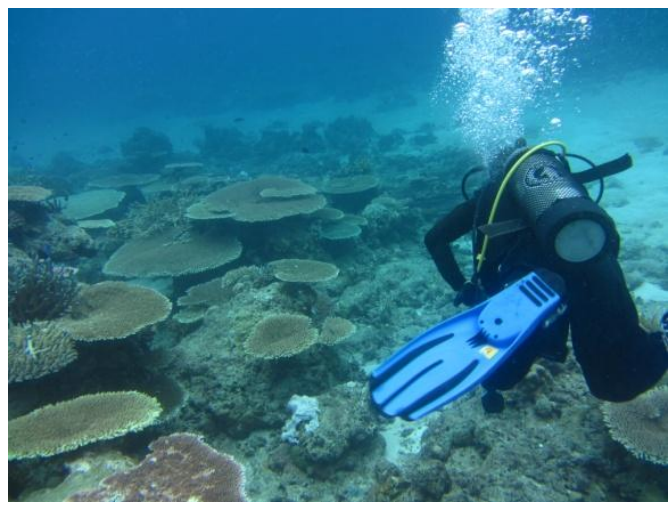

Gambar 4. Observasi dan peliputan bawah air dilakukan dengan penyelaman;

Figure 4. Underwater observation and reporting done by diving method

Sumber: Hasil survei dan penyelaman, 2016

\section{HASIL DAN PEMBAHASAN}

\section{Identifikasi Situs Karang Panjang}

Situs Karang Panjang oleh masyarakat lokal dikenal sebagai Situs Kapal Teh. Situs dapat diidentifikasi mulai dari kedalaman $6,8 \mathrm{~m}$ (pada penyelaman) hingga 10 meter (pada citra sonar). Orientasi arah karam pada Barat Daya - Timur Laut. Berada di sekitar kawasan Perairan Karang Panjang yang berjarak sekitar $\pm 6,9-7$ mil laut dari dermaga Tanjung Batu, Desa Air Payang atau \pm 13,15 mil laut dari dermaga Tanjung Pala. Dihitung jarak dari pulau terdepan NKRI yaitu Pulau Sekatung sekitar 14,76 mil laut. Sedangkan dari Pulau Semiun, berkisar 13 mil laut. Keduanya merupakan pulau terdepan NKRI tak berpenduduk. Tidak jauh dari lokasi situs $(2,44$ mil laut) terdapat Situs Batu Imung yang dari kisah tutur masyarakatnya diduga bagian dari 7 kapal pecah yang merupakan legenda asal mula Pulau Laut. Dari hasil observasi geologi pada pulau ini, menunjukkan bahwa Situs Batu Imung merupakan singkapan tubuh batuan ofiolit rijangradiolaria berwarna kemerahan dan bersifat karbonatan. Ofiolit tersebut merupakan sebuah bongkahan berukuran sangat besar yang tertanam dalam sedimen Kuarter, merupakan salah satu bukti tektonik pembentukan Sundaland pada jalur subduksi Pra-Tersier.

Pada areal situs diidentifikasi terumbu karang dengan lebar mencapai 4 meter (Gambar 5). Bentuk pertumbuhan didominasi oleh jenis tabulate/karang meja. Beberapa jenis bentuk pertumbuhan lainnya antara lain branching, massive dan sub-massive, foliase, dan encrusting. Situs tersebar dengan beberapa bagian kapal yang telah ditutupi oleh terumbu karang yang hampir di atas $70 \%$ tutupannya dengan tingkat keragaman dan biodiversitas yang tinggi (Johan, 2016). Kedalaman kolom air cukup dangkal, pada kisaran 5- 15 meter. Disamping itu, pada lingkungan Situs ditemukan banyak biota ikan hias seperti angelfish. Pada situs ditemukan juga indikasi terumbu karang dengan zat bioaktif dari jenis soft coral (Gambar 6). Menurut Yap dan Gomez (1984), daya dukung lingkungan perairan Situs dapat dianggap memiliki nilai penting bila ekosistem terumbu karangnya memiliki tutupan $50-74,9 \%$ (kriteria bagus) dan lebih dari $75 \%$ (kriteria sangat bagus) yang dapat mendukung pemanfaatan situs secara in situ. Dalam penelitian ini tidak dilakukan perhitungan daya dukung lingkungan, namun mengacu pada hasil observasi bawah laut serta dikaitkan dengan kriteria di atas dapat dikatakan bahwa panorama bawah laut dan daya dukung lingkungannya masuk kategori yang bagus.

JURNAL KELAUTAN NASIONAL, Vol. 11, No. 1, April 2016, Hal 11- 20 

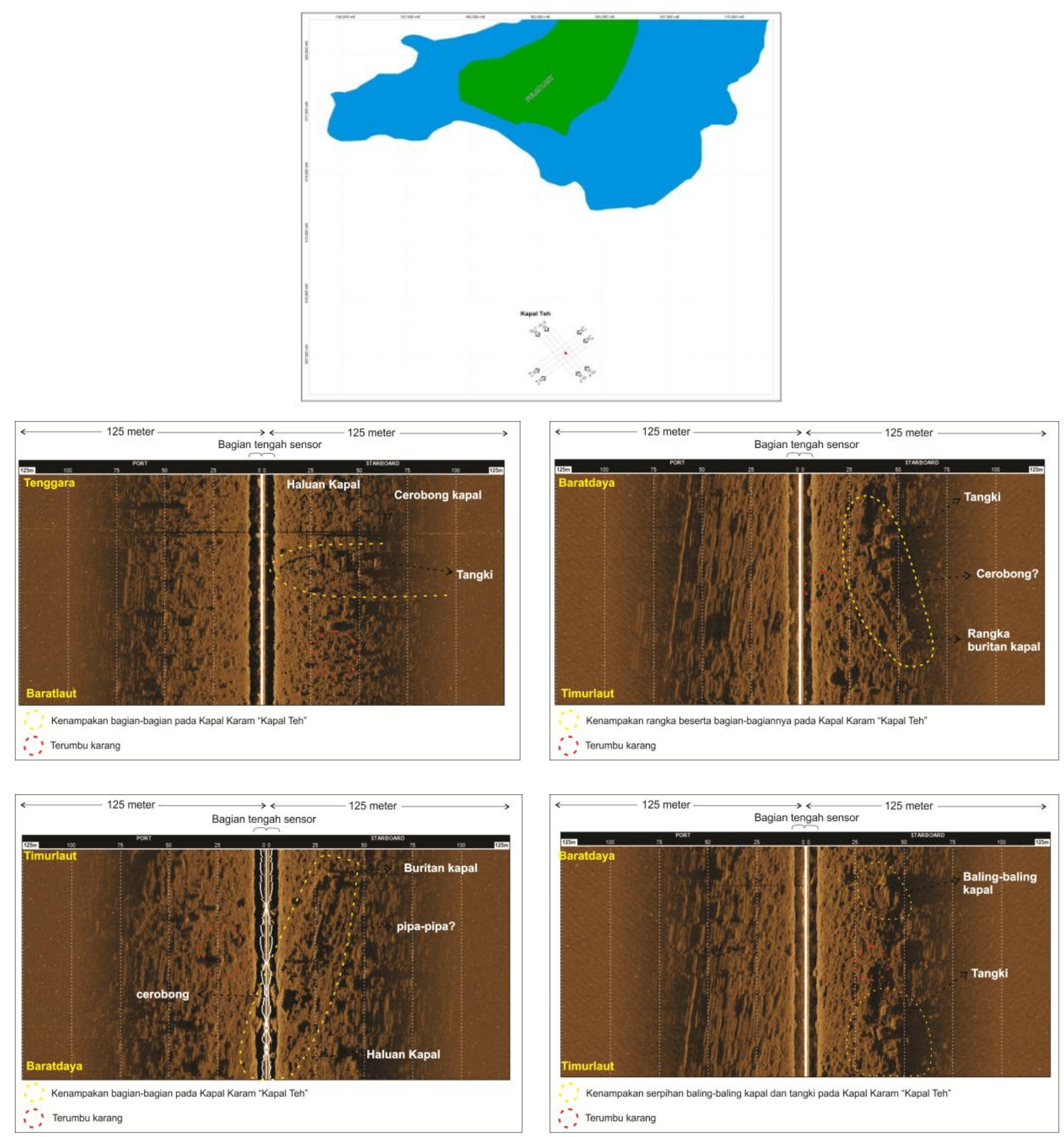

Gambar 7. Peta lintasan dan hasil identifikasi Situs Karang Panjang atau dikenal juga dengan nama Situs Kapal Teh menggunakan side scan sonar, dalam gambar di atas ditunjukkan bahwa struktur dan bagian-bagian kapal karam yang masih dapat diidentifikasi diantaranya haluan dan buritan kapal, struktur rangka kapal, cerobong, baling-baling, serta tangki

Figure 7. Route map and result identified of Karang Panjang shipwreck site or the best known by Kapal Teh Shipwreck using side scan sonar, the pictures showed the structure of the shipwreck still was identified, such as the ship-bow, the stern of ship, the hull of ship, the chimney of ship, propeller, the boiler and the tank of ship

Hasil rekaman side scan sonar yang juga telah diverifikasi dengan observasi melalui penyelaman pada lintasan Crossline (CL) - 3 dari Barat Laut ke Tenggara menemukan adanya haluan kapal, cerobong kapal dan tangki (Gambar 7). Sedangkan, hasil rekaman side scan sonar pada lintasan in-line (IL)-3 dari Barat Daya ke Timur Laut diidentifikasikan buritan kapal, pipa-pipa kapal, haluan kapal dan cerobong (Gambar 7). Pada rekaman side scan sonar pada lintasan inline IL-3 dengan arah Barat Daya ke Timur Laut juga didapatkan gambaran tangki, cerobong dan rangka buritan kapal (Gambar 7) dan hasil

Identifikasi Situs Kapal Karam Bersejarah "Karang Panjang” Di Perairan Pulau Laut Natuna - Ira Dillenia dan Rainer 
rekaman side scan sonar masih ke arah barat daya ke timur laut juga mengidentifikasi gambaran bentuk baling-baling kapal dan tangki (gambar 6). Dimensi panjang kapal yang diinterpretasi oleh rekaman ini memiliki panjang sekitar $70-75$ meter dengan lebar diperkirakan sekitar $20-25$ meter.

Hasil observasi penyelaman menunjukkan beberapa bagian struktur kapal tersebut masih dapat diidentifikasi, umumnya telah tertutup terumbu karang, berbahan besi karena sangat kokoh dan bisa ditempeli oleh berbagai jenis terumbu karang. Sementara itu beberapa bagian yang rusak dimungkinkan berasal dari kayu sehingga saat ini sudah tidak dapat teridentifikasi. Kawasan situs juga didominasi oleh substrat batuan dasar yang keras yang mendominasi area tersebut dengan posisi topografi yang relatif landai pada kedalaman \pm 8 meter, sehingga situs relatif aman dari pengaruh pasang surut dan maksimal dalam penerimaan nutrien, posisi yang relatif terlindung dari Laut Cina Selatan sehingga aman dari badai dan arus yang besar. Interaksi ikan karang dengan terumbu karang juga tinggi pada wilayah situs, terlihat dari ditemukannya beberapa ikan indikator, ikan mayor, dan ikan target (Damanhuri, 2015). Banyaknya ikan karang yang ditemukan tentunya akan menjadi obyek panorama bawah laut yang indah bagi aktivitas penyelaman dan wisata bahari.

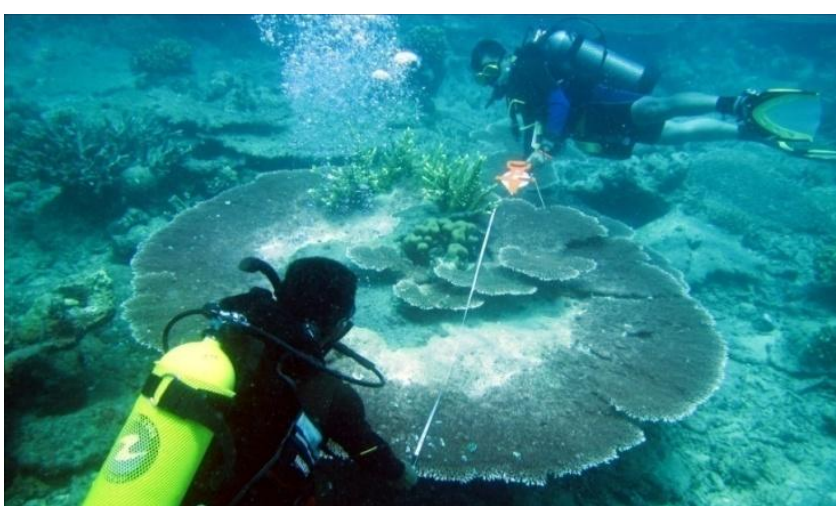

Gambar 5. Terumbu karang tabulate pada lokasi Situs mencapai lebar hingga 4 meter.

Figure 5. The coral reef tabulate on the shipwreck reach out $4 m$ of wide

Sumber: Hasil survei dan penyelaman, 2016

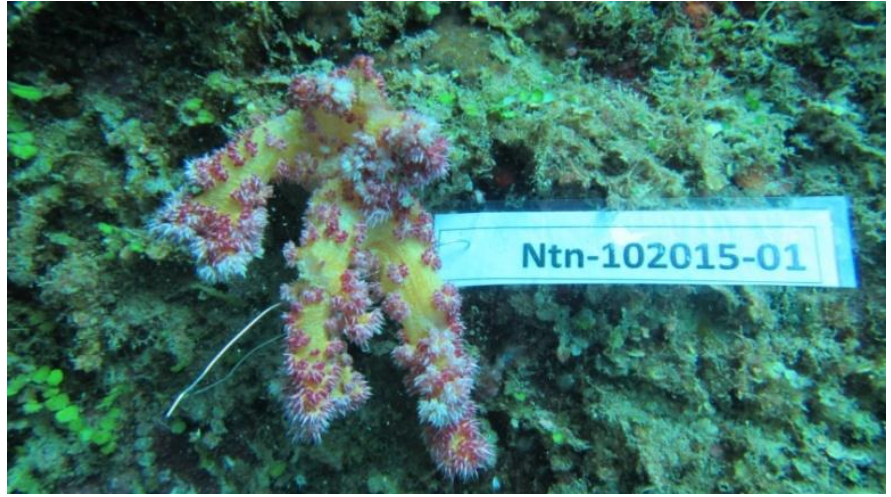

Gambar 6. Ditemukan Indikasi kandungan zat bioaktif dari soft coral yang menempel pada situs

Figure 6. Identified of bio-active subtrate from soft coral on the site

Sumber: Hasil survei dan penyelaman, 2016

\section{Interpretasi Jenis Kapal Karam dan Aspek Historis}

Bila mengacu pada bagian-bagian struktur kapal yang telah diidentifikasi pada pembahasan sebelumnya, indikasinya mengarah pada bagian dari kapal uap berbahan campuran besi dan kayu yang memiliki cerobong dan tenaga penggerak bermesin uap. Identifikasi tangki kapal berdasarkan side scan sonar, melalui verifikasi penyelaman tangki tersebut adalah bagian-bagian mesin uap (boiler) yang sudah tidah utuh dan menyebar tidak merata serta diselimuti terumbu karang (Gambar 8). Struktur kapal sudah berbahan besi, menunjukkan era atau masa mulai diciptakannya yaitu saat Revolusi Industri di Inggris awal abad ke-19 (Mc. Carthy, 2006). Struktur kapal teh memiliki kemiripan bentuk dengan struktur kapal uap pertama Inggris, SS Great Britain yang diciptakan oleh Isambard Kingdom Brunel, seorang Insinyur dari Inggris pada tahun 1836-1837 (Wilkinson, 2002; Batchelor, 2006) seperti terlihat pada Gambar 9. Berdasarkan analisis bentuk dan korelasinya dengan data arsip historis, diinterpretasikan kapal karam pada Situs Karang Panjang (Kapal Teh) ini merupakan salah satu kapal dagang Inggris, bermesin uap dan telah memiliki baling-baling, serta telah mampu menyebrang samudera hingga karam di Perairan Pulau Laut. Situs Karang Panjang bagian struktur kapalnya sudah tidak utuh lagi dan diselimuti terumbu karang. Interaksi bagian kapal karam dan ekosistem terumbu karang menjadikan obyek penyelaman yang sangat menarik melalui pemandangan biodiversitas bawah laut yang menawan. Hal ini

JURNAL KELAUTAN NASIONAL, Vol. 11, No. 1, April 2016, Hal 11- 20 
menjadikan dasar bagi gagasan menjadikan Situs ini sebagai daya tarik wisata bahari Pulau Terdepan NKRI.

Aspek historis dan kisah karamnya kapal juga didapatkan dari sumber lisan hasil wawancara dengan tokoh masyarakat bernama Bapak Muhammad Azham (Pak Azham) yang telah berusia 76 tahun. Menurut pengakuannya, beliau mendapat cerita dan informasi dari ayahnya, Bapak M. Nuh yang wafat pada usia 80 tahun, bahwa kapal pada Situs Karang Panjang tersebut telah tenggelam saat kakek mereka masih hidup. Berdasarkan wawancara ini, dapat dianalisis secara ilustratif perkiraan waktu karamnya kapal yaitu perhitungan umur kapal dihitung dari tahun sekarang (2016) dikurangi penjumlahan usia Pak Azham dan Ayahnya $(70+80=150$ tahun). Jadi, kapal tersebut dapat diperkirakan telah berumur lebih dari 150 tahun, dengan perkiraan tenggelam setidaknya di atas tahun 1866 (ilustrasi perhitungan: $2016-150=1866$ ). Sumber lisan juga menyebutkan bahwa kapal saat itu membawa muatan teh yang sangat banyak, sehingga saat kapal karam bubuk teh telah tumpah ke laut dan membuat laut menjadi merah kecoklat-coklatan seperti teh. Hal ini yang menjadikan Situs Karang Panjang secara lokal dikenal dengan nama Situs Kapal Teh. Dalam observasi lapangan, ditunjukkan pula beberapa pohon teh yang dikatakan tokoh masyarakat itu yang masih tumbuh hingga sekarang di beberapa tempat pada pesisir Pulau laut Natuna (Gambar 10).

Mengacu pada data tersebut dan dikorelasikan dengan tinjauan historisnya, maka diperkirakan kapal merupakan kapal dagang Inggris dari masa era tea trading antara Inggris (English Indian Company - EIC) dan Tiongkok yang dimulai pada masa tahun 1765 dan sempat terhenti pada tahun 1833 akibat perang dingin Tiongkok dengan Inggris, sehingga semua pelabuhan niaga di Tiongkok ditutup untuk pedagang asing, khususnya Inggris. Namun setelah perang dingin berakhir tahun 1842 dan adanya pembukaan terusan Suez tahun 1869, peniagaan dimulai kembali hingga tahun 1880. Sehingga kapal bisa diperkirakan merupakan kapal dagang Inggris dengan jenis kapal uap yang berasal dari tahun 1869 - 1880 yang masuk ke perairan Nusantara akibat tertutupnya Pelabuhan Tiongkok tersebut untuk mencari komoditas teh sebagai alternatif sumber teh tersebut yang sebelumnya sangat bergantung pada pasokan dari Tiongkok.

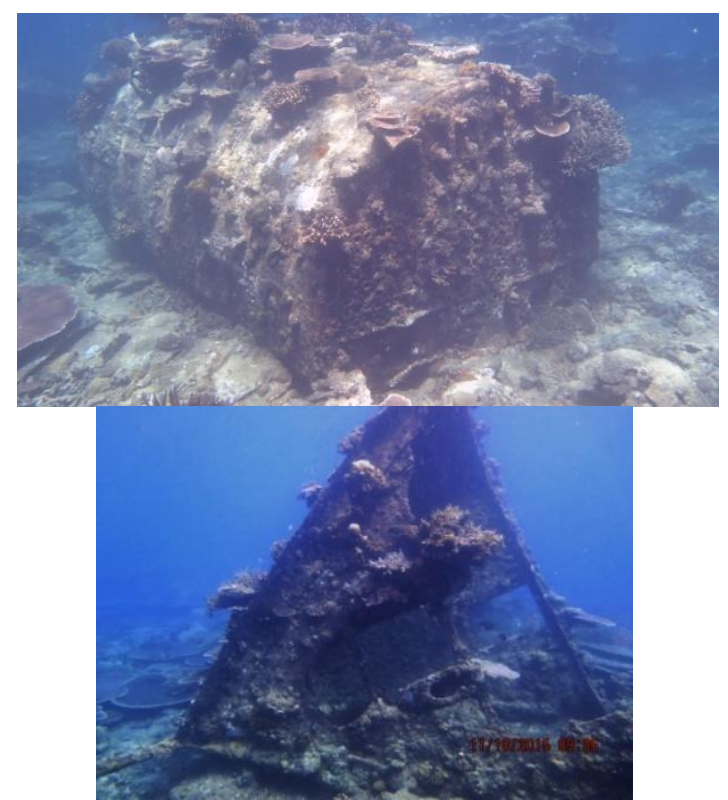

Gambar 8. Bagian mesin uap (boiler) yang sudah tidak utuh (gambar kiri); Bagian haluan kapal yang diselimuti terumbu karang;

Figure 8. the structure of steam-ship (boiler); the shipbow; the stern-bow, covered by corals Sumber: Hasil survei dan penyelaman., 2016

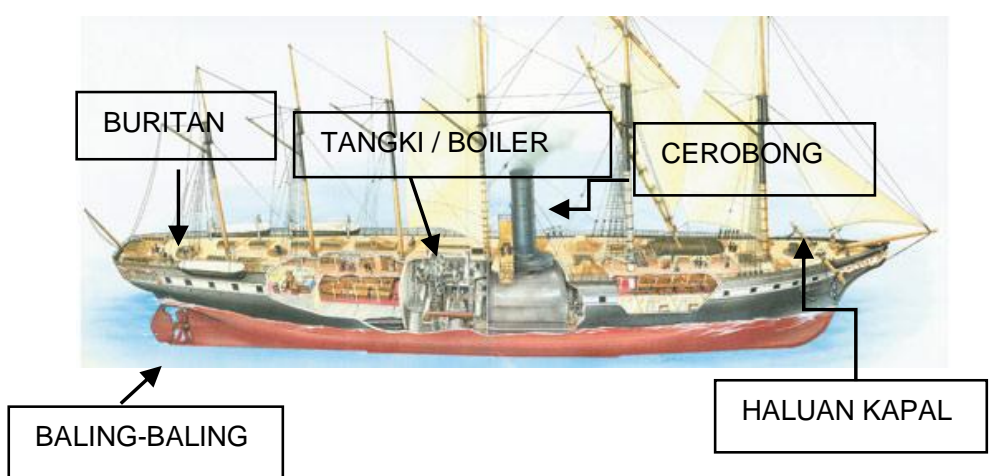

Gambar 9. Desain SS Great Britain of 1843, oleh Isambard Kingdom Brunel.

Figure 9. SS Great Britain design of 1843 by Isambard Kingdom Brunel

Sumber: Modifikasi dari Wilkinson (2002). 


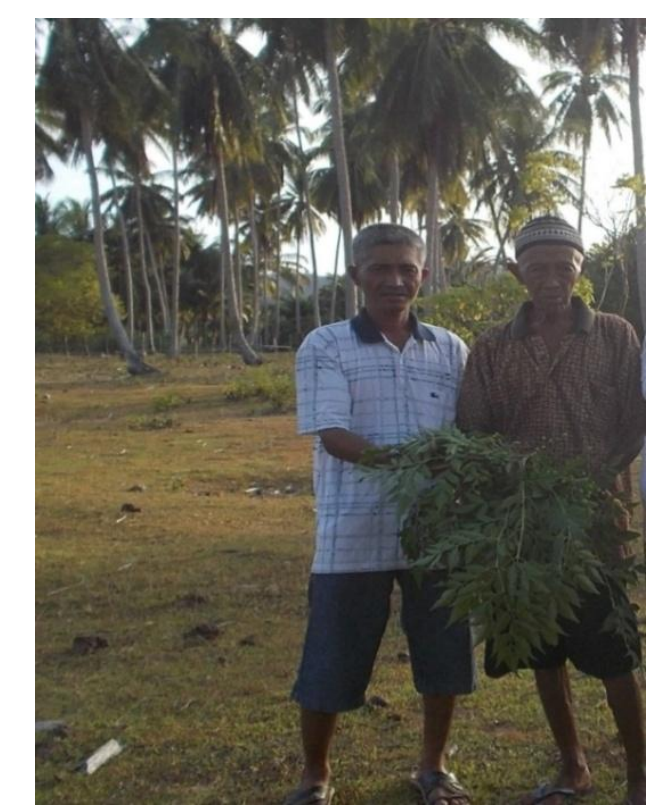

Gambar 10. Foto tokoh masyarakat lokal selaku sumber lisan dengan potongan pohon teh yang dimaksud dalam tulisan ini (lingkaran kuning pada foto).

Figure 10. Picture of the tealeaf verified the shipwreck history, It was hold by the local people whom became the historical resource for the Karang Panjang shipwreck in Natuna waters

Sumber: Hasil survei dan wawancara, 2016

\section{Analisis Nilai Penting Kesejarahan Perairan Situs Karang Panjang}

Nilai penting kesejarahan dapat ditetapkan apabila sumber daya arkeologi tersebut menjadi bukti yang berbobot dari peristiwa yang terjadi pada masa prasejarah dan sejarah, berkaitan erat dengan tokoh-tokoh sejarah, atau menjadi bukti perkembangan penting dalam bidang tertentu. Nilai penting ilmu pengetahuan dapat ditetapkan apabila sumberdaya arkeologi tersebut mempunyai potensi untuk diteliti lebih lanjut dalam rangka menjawab masalah-masalah dalam bidang keilmuan tertentu atau mengandung informasi yang sangat khusus (Tanudirjo, 2010).

Sejak abad 17, kebiasaan minum teh di negaranegara Eropa, seperti Inggris, Spanyol, Prancis, Jerman hingga Skandinavia menjadi sebuah budaya, khususnya bagi keluarga-keluarga kerajaan. Pada abad ke-18, telah dimulai kebiasaan minum teh yang dapat dinikmati di cafe-cafe dan rumah-rumah keluarga biasa di Inggris dan Amerika. Bahkan saat Perang Dunia I, teh sangat populer bahkan dijadikan pengganti dari minuman beralkohol di negara-negara barat. Tuntutan pasar Eropa semakin tinggi terhadap teh yang sangat bergantung pada hasil impor dari Tiongkok, terutama untuk black tea (teh hitam ) dan green tea (teh hijau). Daerah penghasil utama teh di Tiongkok adalah dari Propinsi Fujian, Guangdong, Anhui, Zhejiang dan Jiangsu (Ukers, 1935). Sehingga, akibat tingginya tingkat ekspor teh dari Tiongkok ke negara-negara Barat, menimbulkan sebuah istilah dari para ilmuwan saat itu yang menyebutkan Maritime Silk Road juga dengan sebutan Maritime Tea Road (Reid, 1993).

Semula, VOC lah yang menjadi importir niaga tea trade dari Tiongkok melalui Batavia (Kepulauan Nussantara) hingga menuju negara-negara Eropa. VOC mendapatkan keuntungan yang sangat besar dari perniagaan ini, sehingga mulai tahun 1765 hingga 1774 Inggris tidak mau ketinggalan dalam perniagaan teh tersebut (Ukers, 1935). Lebih dari 50\% bubuk teh terbaik diimpor oleh British East India Company (berkedudukan di India) langsung dari Fujian dan Guandong di Cina melewati Laut Tiongkok Selatan, Perairan Natuna dan menuju India. Dan pada awal abad ke-19 meningkat menjadi $90 \%$ bubuk teh diimpor oleh Inggris dari Tiongkok melintasi Laut Tiongkok Selatan dan Natuna.

Dengan hasil identifikasi Situs Karang Panjang (Kapal Teh), maka diharapkan akan semakin memperkuat nilai sejarah kemaritiman Perairan Pulau Laut Natuna. Secara historis, kawasan perairan Pulau Laut Natuna menjadi bagian penting arus lintas laut kapal dagang dunia saat berlangsungnya Maritime Tea Road (Gambar 11). Secara keseluruhan, aspek historis ini akan berpadu dengan keindahan alam bawah laut dan keunikan Situs Kapal Karam Bersejarah sehingga dapat mendukung pemanfaatan Situs sebagai obyek wisata bahari dan selam berkelanjutan bagi kesejahteraan masyarakatnya dan sumber sejarah IPTEK kemaritiman Nusantara. Secara strategis, wilayah perairan Natuna dan khususunya Pulau Laut sebagai kawasan Pulau terdepan NKRI diharapkan akan dijaga oleh peran aktif masyarakatnya dari kemungkinan invasi asing melalui pertumbuhan dan perkembangan ekonomi berkelanjutan tersebut. 


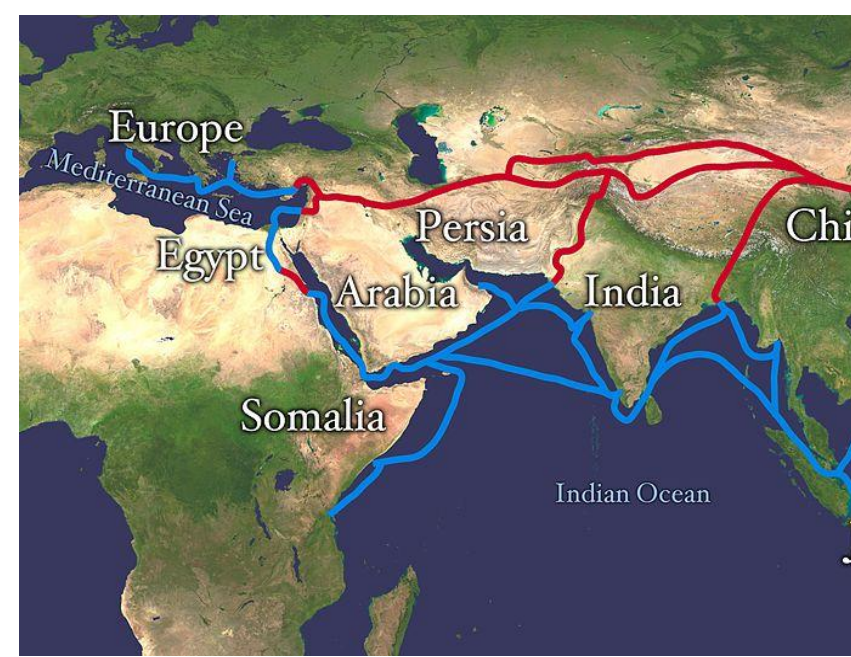

Gambar 11. Peta jalur Maritime Tea Road yang melintasi Perairan Natuna.

Picture 11. Maritime Tea Road passed on the Natuna waters

Sumber: Modifikasi dari Maritime Silk Road Map (Li Qingxin, 2006).

\section{KESIMPULAN DAN SARAN}

Situs Karang Panjang terdiri atas sisa-sisa struktur kapal kayu dan besi yang tersebar dan tertutup oleh terumbu karang dengan panorama bawah laut yang indah didukung keanekaragaman jenis ikan karang yang berinteraksi didalamya. Berdasarkan analisis citra side scan sonar, observasi penyelaman, dan aspek korelasi kesejarahannya, Situs dapat diinterpretasikan dari jenis kapal uap milik perusahaan dagang Inggris (EIC) dari masa tahun antara 1869 - 1880 yang berkedudukan di India. Kapal diduga membawa barang komoditas teh yang saat itu (awal abad ke-19) menjadi trend dan permintaan impor terbesar negara negara Eropa khususnya Inggris terhadap negara eksportir teh terbesar yaitu Propinsi Fujian dan Guangdong Tiongkok. Jalur perlintasan yang saat itu terkenal dengan sebutan Maritime Tea Road, salah satunya merupakan jalur yang melintasi Perairan Laut Tiongkok Selatan dan Perairan Natuna.

Situs Karang Panjang merupakan bukti nilai penting dari perairan Natuna jika berkaca dari kesejarahan. Kawasan Natuna, khususnya Pulau Laut telah dilewati dan menjadi perlintasan kapalkapal pada masa Maritim Tea Road dari Timur (Tiongkok) ke/dan menuju Barat (Eropa). Situs Karang Panjang merupakan situs kapal karam bersejarah yang telah menyatu dengan ekosistem bawah lautnya. Hal ini menjadikan Situs Karang Panjang berpotensi menjadi obyek wisata bahari selam kapal karam (wreckdive) dalam kerangka gagasan Marine Eco-Archaeological Park untuk menumbuhkan aktivitas perekonomian Pulau Terdepan NKRI pada Pulau Laut Natuna.

\section{DAFTAR PUSTAKA}

Batchelor, John and Christoper Chant. 2006. The Complete Encylopedia of Sailing Ships: 200 BC - 2006 AD, Rebo International b.v. Lisse. England

Damanhuri, Harfiandri. 2015. Laporan Penelitian Sebaran Terumbu Karang di Perairan Pulau Laut, Natuna. Puslitbang Sumber Daya Laut dan Pesisir, Kementerian Kelautan dan Perikanan.

Dillenia, Nia, Rainer Troa \& Eko.T. 2012. Kajian Pengelolaan Sumberdaya Arkeologi Laut Berbasis Ekosistem Pesisir Laut Natuna. Prosiding Seminar Hasil Penelitian Terbaik Tahun 2012, hal. 89-99. Badan Penelitian dan Pengembangan Kelautan dan Perikanan.

Gomez ED and Yap HT. 1984. Monitoring reef condition.Dalam Kenchington $\mathrm{R}$ A. and B. Hudson E. T. (ed). Coral reef Management Hand Book. Unesco Regional Office for Science and Technology for South East Asia. Jakarta. $171 \mathrm{p}$.

Green, Jeremy.2004. Maritime Archaeology: A Technical Handbook second edition, Elsevier, Oxford UK.

Gron, O. LO Boldrel., D. Cvikel., Y. Kahnov., E. Galili., JP Herman., D. Naevestad., M. Reitan. 2015. Detection and Mapping of shipwreck embedded in sea floor sedimens. Journal of Archaeological Science. Elsevier.

Harkatiningsih, Naniek. 2010. Laporan Penelitian Sebaran Keramik Natuna. Pusat Penelitian Arkeologi Nasional, Kementerian Kebudayaan dan Pariwisata, Jakarta. 
Johan, Ovri. 2015. Asosiasi Karang dan Biota Lain dengan Kapal tenggelam di Perairan Natuna, Indonesia, Laporan Survei Puslitbang Sumber Daya Laut dan Pesisir, Kementerian Kelautan dan Perikanan.

McCarthy, Michael. 2002. Iron and Steamship Archaeology : Success and Failure on the SS Xanto, Kluwer Academic Publisher, New York..

Mukleroy, Keith. 2014. Introduction of Maritime Archaeology in A Reader of Substantive and Theoretical Contribution, hal. 23 -37. Springer Science+Business Media, New York.

Qingxin, Li. 2006. Maritime Silk Road (Translated by William W.Wang), China Intercontinental Press.

Reid. Struad. 1993. The Silk and Spices Routes. Exploration by Sea. Unesco Integral Study of the Silk Road.Belitha Press. London.

Schottenhammer, Angela. 2012, The China Seas in the World History: A General Outline of the Role of Chinese and East Asian Maritime Space from its Origins to C.1800, Journal of Marine and Island Cultures 1 (2). Institition for Marine and Island Cultures, Mokpo National University . pp.63-86.

Tanudirjo, Daud Aris. 2009. Nilai Penting Sumberdaya Budaya, UGM Press, Yogyakarta.

Troa, Rainer et. al. 2015. Laporan Penelitian Potensi Sumberdaya Perairan Pulau Laut Natuna. Puslitbang Sumberdaya Laut dan Pesisir, Kementerian Kelautan dan Perikanan, Jakarta.

Ukers, William H. 1935. All About Tea: Vols. I and II, The Tea and CoffeeTrade Journal, New York.

UNESCO. 2006. The Benefit of the Protection of Underwater Cultural Heritage for Sustainable Growth, Tourism and Urban Development.

Wibisono, Sonny C. 2014. Arkeologi Natuna : Koridor Maritim di Perairan Laut Cina Selatan. Kalpataru Majalah Arkeologi Vol.23 No 2 Hal. 81-150.

Wikinson, Philip. 2002. The Best - Ever Book of Ships, Kingfisher Publication Plc.

JURNAL KELAUTAN NASIONAL, Vol. 11, No. 1, April 2016, Hal 11- 20 